\title{
Uncertainty in climate change impacts on water resources in the Rio Grande Basin, Brazil
}

\author{
M. T. Nóbrega ${ }^{1}$, W. Collischonn ${ }^{2}$, C. E. M. Tucci ${ }^{2}$, and A. R. Paz ${ }^{3}$ \\ ${ }^{1}$ Agencia Nacional de Aguas (National Water Agency - Brazil), SPS, Area 5, Quadra 3, Bloco "L", Brazil \\ ${ }^{2}$ Instituto de Pesquisas Hidráulicas, Universidade Federal do Rio Grande do Sul, Porto Alegre, Brazil \\ ${ }^{3}$ Depto de Engenharia Civil e Ambiental, Universidade Federal da Paraíba, João Pessoa, Brazil
}

Received: 31 July 2010 - Published in Hydrol. Earth Syst. Sci. Discuss.: 25 August 2010

Revised: 6 January 2011 - Accepted: 26 January 2011 - Published: 17 February 2011

\begin{abstract}
We quantify uncertainty in the impacts of climate change on the discharge of Rio Grande, a major tributary of the Paraná River in South America and one of the most important basins in Brazil for water supply and hydroelectric power generation. We consider uncertainty in climate projections associated with the greenhouse-gas emission scenarios (A1b, A2, B1, B2) and increases in global mean air temperature of 1 to $6^{\circ} \mathrm{C}$ for the HadCM3 GCM (Global Circulation Model) as well as uncertainties related to GCM structure. For the latter, multimodel runs using 6 GCMs (CCCMA CGCM31, CSIRO Mk30, IPSL CM4, MPI ECHAM5, NCAR CCSM30, UKMO HadGEM1) and HadCM3 as baseline, for a $+2^{\circ} \mathrm{C}$ increase in global mean temperature. Pattern-scaled GCM-outputs are applied to a large-scale hydrological model (MGB-IPH) of Rio Grande Basin. Based on simulations using HadCM3, mean annual river discharge increases, relative to the baseline or control run period (1961-1990), by $+5 \%$ to $+10 \%$ under the SRES emissions scenarios and from $+8 \%$ to $+51 \%$ with prescribed increases in global mean air temperature of between 1 and $6^{\circ} \mathrm{C}$. Substantial uncertainty in projected changes to mean river discharge ( $-28 \%$ to $+13 \%$ ) under the $2^{\circ} \mathrm{C}$ warming scenario is, however, associated with the choice of GCM. We conclude that, in the case of Rio Grande Basin, the most important source of uncertainty derives from the GCM rather than the emission scenario or the magnitude of rise in mean global temperature.
\end{abstract}

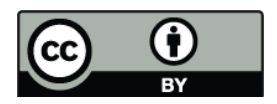

Correspondence to: $\mathrm{W}$. Collischonn (collischonn@iph.ufrgs.br)

\section{Introduction}

The well-being of human societies is closely associated with climate and thereby influenced by climate variability. This relationship is especially strong in regions where the economy is based on rain-fed agriculture (e.g. sub-Saharan Africa) or where there is strong dependence upon river flow for the generation of electricity (e.g. Brazil). Multi-annual climate variability (e.g. sustained drought) is of particular concern to water managers and has been observed in the discharge of rivers around the world (e.g. Dettinger and Diaz, 2000; Peel et al., 2001; Timilsena et al., 2009). In South America, this variability has been recorded in the Paraguay River and its tributaries (Collischonn et al., 2001) and the Paraná River (Robertson and Mechoso, 1998; Barros et al., 2006).

The impacts of climate change upon river flow, including the incidence and magnitude of periods of sustained high or low flow and, in turn, their implications for water resources management are important areas of research. In Brazil, one of the first analyses of the regional impacts of climate change on water resources was conducted by Tucci and Damiani (1994). Using the IPH2 rainfall runoff model (Motta and Tucci, 1984; Tucci and Clarke, 1980) and climate predictions for 2040-2060 from three different Global Circulation Models (GCM), mean stream flow in the Brazilian parts of the Uruguay River Basin was projected to change by between $-15 \%$ and $+25 \%$.

Tomasella et al. (2008) analysed the impacts of climate change on the discharge of the rivers Araguaia and Tocantins that flow from central to northern Brazil. They used the MGB-IPH hydrological model (Collischonn et al., 2007a) driven by climate projections from one GCM (HadCM3)

Published by Copernicus Publications on behalf of the European Geosciences Union. 

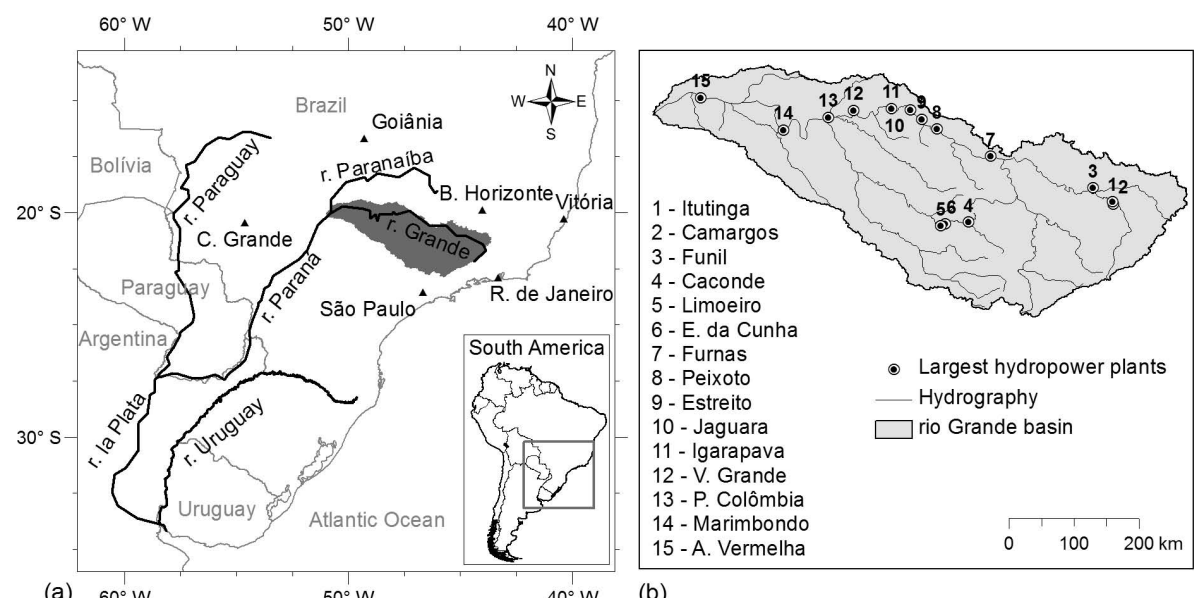

(a) $60^{\circ} \mathrm{W}$

$50^{\circ} \mathrm{W}$

(b)

Fig. 1. Maps of (a) regional drainage including the study area (Rio Grande basin) and (b) main hydropower plants in the Rio Grande basin.

that were dynamically downscaled to a $40 \mathrm{~km}$ grid resolution using the ETA Regional Climate Model (RCM) (Chou et al., 2000). Discharge of the River Tocantins at the Tucuruí hydro-electric dam (drainage area $758000 \mathrm{~km}^{2}$ ) was projected to decrease by $20 \%$ for the 2080-2099 period compared to a 1970-1999 baseline. For water resources management, principally for hydro-electric power (HEP) generation relying on sustained river flow, a more important result is the suggestion that low flows (those exceeded $90 \%$ of the time) would decrease by $58 \%$.

One of the most important concerns related to climate change in Brazil is therefore the implications for HEP generation. The country relies heavily on renewable resources and HEP is responsible for almost all $(\sim 90 \%)$ of Brazil's electric power production. Schaeffer et al. (2008) evaluated the impacts of climate change on the Brazilian energy sector with a particular emphasis on electricity. They used statistical models to generate reference time series of stream flow for several hydropower plants. Subsequently, the statistical models parameters were perturbed (mean and standard deviation) according to expected changes associated with climate change scenarios generated using PRECIS (Providing REgional Climates for Impacts Studies) model (Ambrizzi et al., 2007; Marengo, 2007). Two emission scenarios were considered; A2 (high emission) and B2 (low emission) although the PRECIS projections draw from just one GCM (HadCM3). It was concluded that most of the Brazilian rivers which are used for HEP generation would face a reduction in discharge due to climate change.

Most analyses of climate change impacts on river discharge in South America have, to date, relied upon climate projections from a single GCM. The results of these assessments should be viewed with caution since the uncertainty associated with model (GCM) structure is not considered. In this paper, we estimate climate change impacts on stream flow in the Rio Grande Basin of South America through the application of a range of climate scenarios to a large-scale distributed hydrological model (MGB-IPH) (Collischonn et al., 2007a). Critically, the range of applied climate scenarios enables the quantification of uncertainty between different GCMs, emission scenarios (A1b, A2, B1, B2) and prescribed increases in global mean air temperature $\left(1\right.$ to $\left.6^{\circ} \mathrm{C}\right)$, including the $2{ }^{\circ} \mathrm{C}$ threshold of "dangerous" climate change (Todd et al., 2010).

\section{The Rio Grande Basin}

The Rio Grande is one of the main, headwater tributaries of the Paraná River and drains an area of approximately $145000 \mathrm{~km}^{2}$ (Fig. 1), which is relatively hilly, ranging in elevation from more than $1800 \mathrm{~m}$ above mean sea level (m a.m.s.l.) to less than $200 \mathrm{~m}$ a.m.s.l. Agricultural land use constitutes more than $70 \%$ of the area whereas natural and planted forests cover approximately $20 \%$. Mean annual rainfall over the basin is approximately $1400 \mathrm{~mm}$ and is concentrated during southern hemisphere summer; actual, annual evapotranspiration averaged over the whole basin is approximately $950 \mathrm{~mm}$. The Rio Grande discharges into the Paranaiba River which marks the start of the Paraná River. Approximately $60 \%$ of HEP generation in Brazil is provided by the Paraná Basin and the river is also very important in terms of energy production further downstream in Paraguay and Argentina. HEP generation in the Rio Grande Basin accounts for $\sim 12 \%$ of Brazil's total (ANEEL, 2005). There are four hydropower plants along the Rio Grande (Marimbondo, Agua Vermelha, Furnas and Estreito) each of them with power generation capacity exceeding $1000 \mathrm{MW}$.

The Furnas reservoir alone has a volume of $17 \mathrm{~km}^{3}$ and is used for regulating flows all over the Paraná River generation cascade, including the Itaipu hydropower plant. Besides its importance for power generation, water resources in the 
region are also essential for irrigation and urban water supplies.

\section{The MGB-IPH hydrological model}

The MGB-IPH hydrological model is a large-scale distributed model (Collischonn et al., 2007a) which includes modules for calculating the soil-water budget, evapotranspiration, flow propagation, and flow routing through a drainage network automatically derived from a digital elevation model (Paz and Collischonn, 2007). The drainage basin is divided into square cells connected by channels. Each cell is further divided in parts, following a Hydrologic Response Unit (HRU) or Grouped Response Unit (GRU) approach (Beven, 2001; Kouwen et al., 1993), which are areas with similar combinations of soil types and land cover or land use. A cell contains a limited number of distinct HRUs (Allasia et al., 2006). Soil-water budget is computed for each HRU of each cell, using rainfall data and evapotranspiration calculated using the Penman-Monteith equation based on data of the following variables: air temperature, relative humidity, wind velocity, solar radiation, and atmospheric pressure. Runoff generated from different HRUs in one cell is summed and flow generated within the cell is routed to the stream network using three linear reservoirs (baseflow, subsurface flow and surface flow). Stream flow is propagated through the river network using the Muskingum-Cunge method. A full description of the model is given by Collischonn et al. (2007a).

MGB-IPH has been employed in a range of large-scale river basins ranging from 6000 to more than 1 million $\mathrm{km}^{2}$, including applications for river flow forecasts based on quantitative precipitation forecasts (Tucci et al., 2003; Collischonn et al., 2005; Collischonn et al., 2007b; Tucci et al., 2008; Bravo et al., 2009), simulations of the impact of climate change on the Tocantins and Araguaia rivers (Tomasella et al., 2008) and tests of Tropical Rainfall Measurement Mission (TRMM) rainfall remote sensing data in the Tapajos river basin (Collischonn et al., 2008).

\section{Model calibration and validation}

Initial calibration and validation of the model was undertaken with input meteorological data provided by records of meteorological stations. Rainfall data derive from a fairly dense gauge network of 273 stations (ANA, 2005), which allows a reasonable spatial representation of precipitation (density of 1 station per $530 \mathrm{~km}^{2}$ ). Daily rainfall in each grid cell of the model was then calculated by an inverse distance weighted method applied on observed precipitation records.

Evapotranspiration is calculated using observed daily or mean-monthly values of temperature, sunshine hours, relative humidity, wind speed and atmospheric pressure using the Penman-Monteith equation. Hydrological model parameters
Table 1. Skill metrics of the hydrological model run with observed precipitation data during the calibration (1970-1980) and validation (1981-2001) periods (NS: Nash-Sutcliffe coefficient of efficiency of daily discharge values; NSlog: Nash-Sutcliffe coefficient of efficiency of the logarithms of daily discharge values; $\Delta V$ : volume bias).

\begin{tabular}{lrrrrrrr}
\hline $\begin{array}{l}\text { Hydropower } \\
\text { plant }\end{array}$ & \multicolumn{3}{c}{ Calibration peridod } & & \multicolumn{3}{c}{ Validation period } \\
\cline { 2 - 3 } \cline { 7 - 8 } \cline { 7 - 8 } & NS & NSlog & $\Delta V(\%)$ & & NS & NSlog & $\Delta V(\%)$ \\
\hline Camargos & 0.91 & 0.93 & 0.02 & & 0.89 & 0.90 & 6.7 \\
Caconde & 0.85 & 0.87 & $<0.01$ & & 0.85 & 0.87 & 3.3 \\
Limoeiro & 0.87 & 0.88 & $<0.01$ & & 0.89 & 0.90 & 2.2 \\
Furnas & 0.93 & 0.93 & $<0.01$ & & 0.91 & 0.91 & 5.9 \\
Peixoto & 0.93 & 0.92 & $<0.01$ & & 0.92 & 0.91 & 6.4 \\
Jaguara & 0.93 & 0.92 & 0.01 & & 0.92 & 0.91 & 6.1 \\
V. Grande & 0.93 & 0.92 & $<0.01$ & & 0.92 & 0.92 & 5.1 \\
P. Colômbia & 0.93 & 0.92 & 0.02 & & 0.92 & 0.93 & 2.4 \\
Marimbondo & 0.93 & 0.93 & 0.05 & & 0.94 & 0.95 & 0.7 \\
A. Vermelha & 0.92 & 0.91 & 0.05 & & 0.95 & 0.95 & 0.7 \\
\hline
\end{tabular}

were calibrated using data from 1970 to 1980 , while the period 1981 to 2001 was used for model validation. The model was calibrated by modifying values of parameters, following the approach described by Collischonn et al. (2007a). The multi-objective MOCOM-UA optimization algorithm (Yapo et al., 1998) was employed using three objectivefunctions: volume bias $(\Delta V)$; Nash-Sutcliffe model efficiency for stream flow (NS); and Nash-Sutcliffe for the logarithms of stream flow (NSlog). These three objective functions were calculated at ten hydropower plants over the basin where observed discharge time series were available (Fig. 1 and Table 1).

As a result of the multi-objective optimization, several Pareto optimal solutions were found. A single solution was chosen from among them with the aim of providing an acceptable trade-off between fitting different parts of the hydrograph and the different objective-functions, as suggested by Bastidas et al. (2002). In both calibration and validation, the values obtained for NS and NSlog ranged between 0.85 and 0.95 at all power plants shown in Table 1 . Values of volume bias were also acceptable, with values less than $0.05 \%$ for calibration and less than $7 \%$ for validation (Table 1).

Subsequently these results were compared to those obtained when the hydrological model was forced with gridded meteorological data. Baseline monthly meteorological data (precipitation totals, minimum and maximum temperature, vapour pressure, cloud cover) were obtained from the gridded $\left(0.5^{\circ} \times 0.5^{\circ}\right)$ CRU TS 3.0 observational dataset (Mitchell and Jones, 2005). Monthly data were disaggregated to a daily resolution following procedures outlined in Todd et al. (2010). The disaggregation method is based on a stochastic model which assumes daily precipitation follows an exponential distribution, with the coefficient of variation of daily precipitation derived from analysis of available 


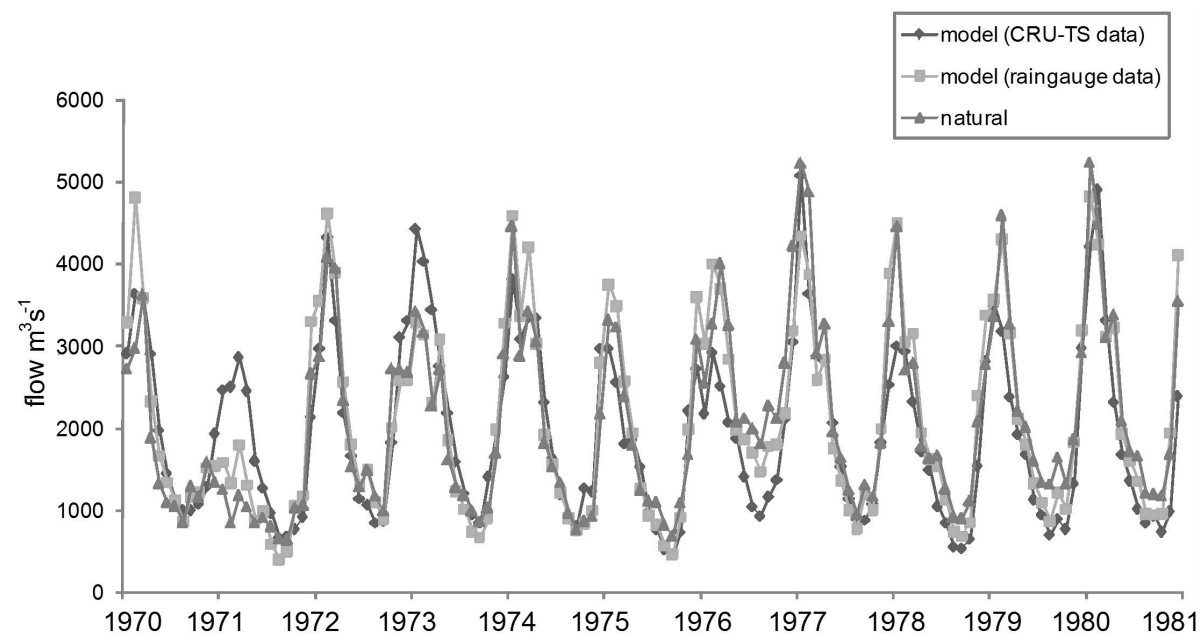

Fig. 2. Calculated stream flow hydrographs at Agua Vermelha reservoir using CRU and raingauge data compared to the observed naturalized hydrograph.

rain gauge data from within each basin. The occurrence of precipitation is described by a simple two-state Markov model with transitional probabilities fixed. Daily rain gauge data, which provides the basis for the coefficient of variation used to generate daily data, were obtained from the Brazilian National Water Agency (ANA). To enable these data to be used within the hydrological model they were reinterpolated to the model's $6^{\prime \prime} \times 6^{\prime \prime}$ resolution using an inverse distance weighted method. Solar radiation was estimated using cloudiness values from the CRU dataset, and relative humidity was estimated using vapour pressure data. Daily values for the variables used to calculate evapotranspiration were considered to be identical to the mean monthly values.

Simulated stream flow at Agua Vermelha reservoir, which is very near to the outlet of the basin, for 1970-1980 is presented in Fig. 2. This figure shows monthly hydrographs derived from the model using both the station meteorological data and the gridded data derived from the CRU dataset. Observed stream flows are also shown in the form of naturalized flows based on the correction of actual observed time series to remove the effects of reservoir operation and consumptive use of water upstream (ONS, 2007). Agreement between the observed and simulated hydrograph calculated using CRU data as input is not as good as that obtained using rain gauge data (Fig. 2). Use of the CRU data results in values of Nash-Sutcliffe (NS) and Log-Nash-Sutcliffe (NSLog) of 0.69 and 0.60 , respectively. In contrast, the use of station records results in NS $=0.88$ and NSLog $=0.88$. These values are slightly different from those in Table 1 , because the values referred here are obtained by comparing observed and calculated monthly values, instead of daily values used in Table 1. Nevertheless, the results using the CRU dataset can be considered reasonable, because the seasonality and the range of stream flow are close to the observed. Average stream flow calculated using the CRU data is $7 \%$ lower than the average calculated using station records, and also $7 \%$ lower than the observed average stream flow.

\section{Climate projections}

Future climate scenarios for temperature (and in turn evapotranspiration) and precipitation were generated using the ClimGen pattern-scaling technique described in Osborn (2009) and Todd et al. (2010). Scenarios were generated for (1) greenhouse-gas emission scenarios (A1b, A2, B1, B2) and (2) prescribed increases in global mean temperature of $1,2,3,4,5$, and $6^{\circ} \mathrm{C}$ using the UKMO HadCM3 GCM as well as (3) A1b emission scenario and prescribed warming of $2{ }^{\circ} \mathrm{C}$ ("dangerous" climate change) using six additional GCMs from the World Climate Research Programme (WCRP) Coupled Model Intercomparison Project phase 3 (CMIP3) multi-model dataset: CCCMA CGCM31, CSIRO Mk30, IPSL CM4, MPI ECHAM5, NCAR CCSM30, and UKMO HadGEM1. Table 2 summarizes the model runs which were evaluated. Baseline (19611990) CRU data were modified so that any trend relating to increasing global mean temperature was removed. This detrended CRU dataset was used for baseline model runs with a "stable climatology" (i.e. no trend) to provide a basis for comparison with the climate change model runs (control run). 

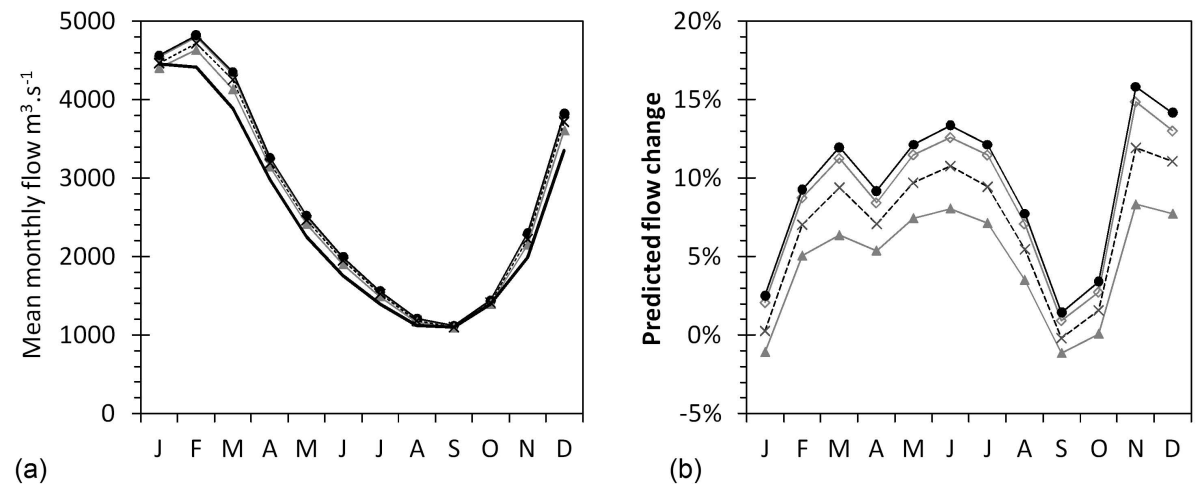

$$
\begin{aligned}
& \rightarrow \text { HadCM3_A1b } \rightarrow \text { HadCM3_A2 } \rightarrow \text { HadCM3_B1 } \\
& -*-H a d C M 3 \_B 2 \quad-\text { Baseline }
\end{aligned}
$$

Fig. 3. Projected changes in mean monthly river flow under different SRES emission scenarios using HadCM3 in the Rio Grande basin (a) and relative to the detrended 1961-1990 baseline or control run (b).

Table 2. Hydrological model runs.

\begin{tabular}{llcl}
\hline Model & Scenario & length & obs. \\
\hline HadCM3 & A1B & $2006-2100$ & \\
HadCM3 & A2 & $2006-2100$ & Hadley \\
HadCM3 & B1 & $2006-2100$ & Center Model \\
HadCM3 & B2 & $2006-2100$ & \\
\hline HadCM3 & $+1{ }^{\circ} \mathrm{C}$ & $2040-2069$ & \\
HadCM3 & $+2{ }^{\circ} \mathrm{C}$ & $2040-2069$ & 1 to $6{ }^{\circ} \mathrm{C}$ \\
HadCM3 & $+3{ }^{\circ} \mathrm{C}$ & $2040-2069$ & increase in \\
HadCM3 & $+4{ }^{\circ} \mathrm{C}$ & $2040-2069$ & average \\
HadCM3 & $+5{ }^{\circ} \mathrm{C}$ & $2040-2069$ & global \\
HadCM3 & $+6{ }^{\circ} \mathrm{C}$ & $2040-2069$ & temperature \\
\hline UKMO HadGEM1 & A1B & $2006-2100$ & \\
CCCMA CGCM31 & A1B & $2006-2100$ & \\
CSIRO mk3.0 A1B & A1B & $2006-2100$ & \\
MPI ECHAM5 & A1B & $2006-2100$ & \\
IPSL CM4 & A1B & $2006-2100$ & \\
NCAR CCSM30 & A1B & $2006-2100$ & \\
\hline CCCMA CGCM31 & $+2{ }^{\circ} \mathrm{C}$ & $2040-2069$ & \\
CSIRO Mk30 & $+2{ }^{\circ} \mathrm{C}$ & $2040-2069$ & $2{ }^{\circ} \mathrm{C}$ increase \\
MPI ECHAM5 & $+2{ }^{\circ} \mathrm{C}$ & $2040-2069$ & in average \\
UKMO HadGEM1 & $+2{ }^{\circ} \mathrm{C}$ & $2040-2069$ & global \\
IPSL CM4 & $+2{ }^{\circ} \mathrm{C}$ & $2040-2069$ & temperature \\
NCAR CCSM30 & $+2{ }^{\circ} \mathrm{C}$ & $2040-2069$ & \\
\hline \multicolumn{1}{c}{ detrend 1961-90 CRU-TS } & $2040-2069$ & Control run \\
Baseline CRU-TS & $1930-2002$ & \\
ONS-naturalized flows & $1930-2002$ & \\
\hline & & $1970-1980$ & observed \\
\hline
\end{tabular}

www.hydrol-earth-syst-sci.net/15/585/2011/

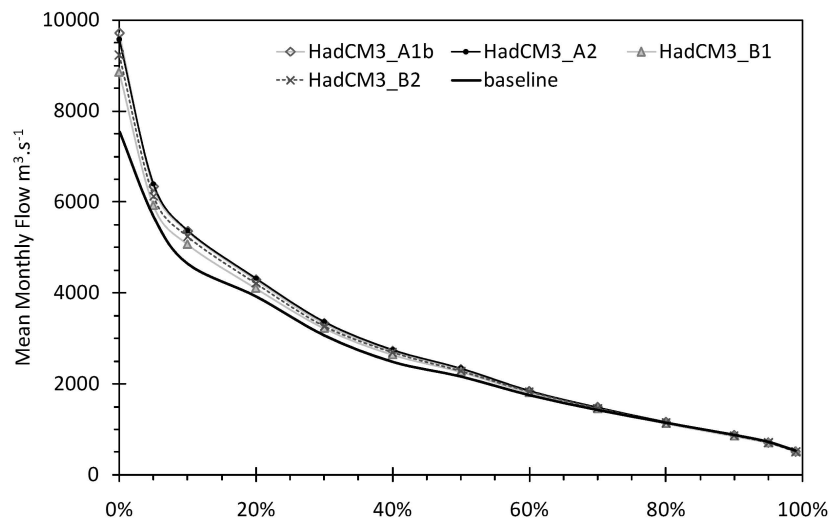

Fig. 4. Projected mean monthly flow duration curves under different SRES emission scenarios using HadCM3 in the Rio Grande basin along with the detrended 1961-1990 baseline or control run.

\section{Results and discussion}

\subsection{Uncertainty in greenhouse-gas emissions}

Table 3 presents projected changes in average river flow at Agua Vermelha reservoir for the model runs which employ results of the HadCM3 GCM and four greenhousegas emission scenarios. An increase in discharge compared to the baseline is projected under all four scenarios. In the case of the most severe emissions scenario, A2, mean river flow increases by $10 \%$. Projected increases are not evenly distributed over the year (Fig. 3). The most important changes occur during the late wet season (from February to July). Less important changes occur during the low flow season (August to October). Indeed, analysis of flowduration curves (Fig. 4) reveals preferential changes to peak flows. In the case of A2, the most severe emission scenario, an increase from $5667 \mathrm{~m}^{3} \mathrm{~s}^{-1}$ (baseline) to $6398 \mathrm{~m}^{3} \mathrm{~s}^{-1}$ is 
Table 3. Hydrological modelling results using the same GCM (HadCM3) and different greenhouse emission scenarios. Control run was calculated using 95 years, from 2006 to 2100 .

\begin{tabular}{lllllr}
\hline & \multicolumn{4}{c}{ Model HadCM3 } \\
\cline { 2 - 6 } & Scenario A1B & Scenario A2 & Scenario B1 & Scenario B2 & $\begin{array}{r}\text { Control } \\
\text { run }\end{array}$ \\
\hline $\begin{array}{l}\text { Average river flow } \\
\left(\mathrm{m}^{3} \mathrm{~s}^{-1}, \% \text { change }\right)\end{array}$ & $2731,+9 \%$ & $2748,+10 \%$ & $2629,+5 \%$ & $2686,+7 \%$ & 2508 \\
\hline $\begin{array}{l}95 \% \text { duration flow } \\
\left(\mathrm{m}^{3} \mathrm{~s}^{-1}, \% \text { change }\right)\end{array}$ & $710,-2 \%$ & $715,-2 \%$ & $707,-3 \%$ & $709,-2 \%$ & 726 \\
\hline $\begin{array}{l}5 \% \text { duration flow } \\
\left(\mathrm{m}^{3} \mathrm{~s}^{-1}, \% \text { change }\right)\end{array}$ & $6335,+12 \%$ & $6398,+13 \%$ & $5924,+5 \%$ & $6127,+8 \%$ & 5667 \\
\hline
\end{tabular}
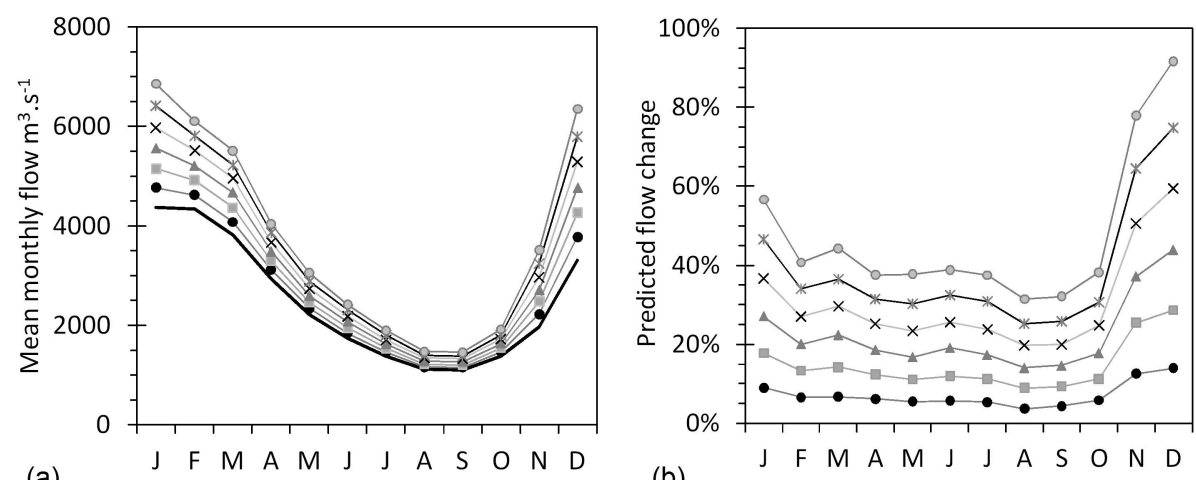

$$
\begin{aligned}
& \text { - } \mathrm{HadCM} 3+1 \mathrm{C}-\mathrm{HadCM} 3+2 \mathrm{C} ₫ \mathrm{HadCM} 3+3 \mathrm{C} \\
& * \mathrm{HadCM} 3+4 \mathrm{C} * \mathrm{HadCM} 3+5 \mathrm{C}-\mathrm{-HadCM} 3+6 \mathrm{C} \\
& \text {-Baseline }
\end{aligned}
$$

Fig. 5. Projected changes in mean monthly river flow under prescribed increases in global mean air temperature using HadCM3 in the Rio Grande basin (a) and relative to the detrended 1961-1990 baseline or control run (b).

projected for $5 \%$ exceedence probability in contrast to a decrease from $726 \mathrm{~m}^{3} \mathrm{~s}^{-1}$ to $715 \mathrm{~m}^{3} \mathrm{~s}^{-1}$ for $95 \%$ exceedance probability duration.

\subsection{Uncertainty in prescribed warming $\left(1\right.$ to $\left.6^{\circ} \mathrm{C}\right)$}

All the scenarios using HadCM3 for increases in global mean temperature project an increase in the discharge of Rio Grande (Table 4). The magnitude of the increase in river discharge rises in proportion to increasing global mean air temperature from $8 \%$ above the baseline for the $1{ }^{\circ} \mathrm{C}$ scenario to $50 \%$ for the $6^{\circ} \mathrm{C}$ scenario. Figure 5 summarises the changes in mean monthly flows for all six scenarios. Most importantly, river discharge changes are projected to occur during the early wet season (November to January). For the scenario which simulates a $6{ }^{\circ} \mathrm{C}$ rise in global mean air temperature, river flows increase by over $90 \%$ in December. A similar trend is presented in flow duration curves (Fig. 6), with increasing global air temperatures resulting in increasing flows

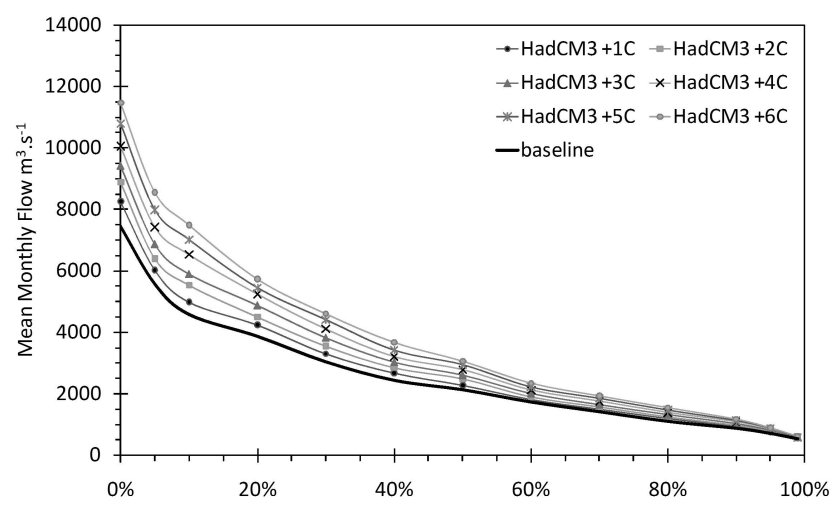

Fig. 6. Projected mean monthly flow duration curves under prescribed increases in global mean air temperature using HadCM3 in the Rio Grande basin along with the detrended 1961-1990 baseline or control run. 
Table 4. Hydrological modelling results using the same GCM (HadCM3) and different mean global temperature increase scenarios. Control run was calculated using 30 years, from 2040 to 2069.

\begin{tabular}{lrrrrrrr}
\hline & $+1{ }^{\circ} \mathrm{C}$ & $+2{ }^{\circ} \mathrm{C}$ & $+3{ }^{\circ} \mathrm{C}$ & $+4{ }^{\circ} \mathrm{C}$ & $+5{ }^{\circ} \mathrm{C}$ & $\begin{array}{r}+6{ }^{\circ} \mathrm{C} \\
\text { run }\end{array}$ & Control \\
\hline $\begin{array}{l}\text { Average river flow } \\
\left(\mathrm{m}^{3} \mathrm{~s}^{-1}, \% \text { change }\right)\end{array}$ & $2666,+8 \%$ & $2865,+16 \%$ & $3070,+24 \%$ & $3283,+33 \%$ & $3495,+41 \%$ & $3715,+50 \%$ & 2475 \\
\hline $\begin{array}{l}95 \% \text { duration flow } \\
\left(\mathrm{m}^{3} \mathrm{~s}^{-1}, \% \text { change }\right)\end{array}$ & $765,+7 \%$ & $801,+15 \%$ & $826,+16 \%$ & $854,+20 \%$ & $874,+23 \%$ & $897,+26 \%$ & 713 \\
\hline $\begin{array}{l}5 \% \text { duration flow } \\
\left(\mathrm{m}^{3} \mathrm{~s}^{-1}, \% \text { change }\right)\end{array}$ & $6037,+8 \%$ & $6405,+15 \%$ & $6873,+23 \%$ & $7430,+33 \%$ & $7988,+43 \%$ & $8564,+53 \%$ & 5579 \\
\hline
\end{tabular}

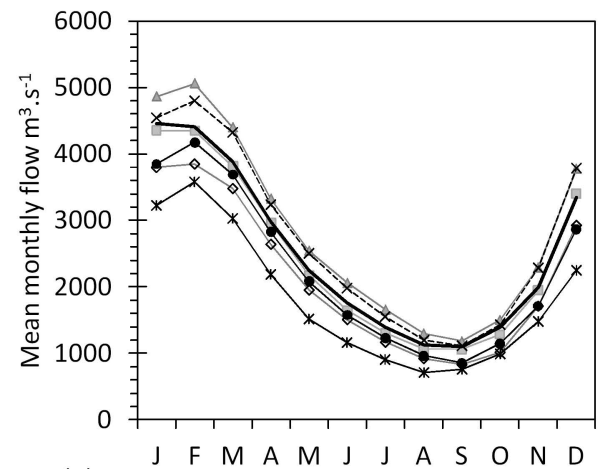

(a)

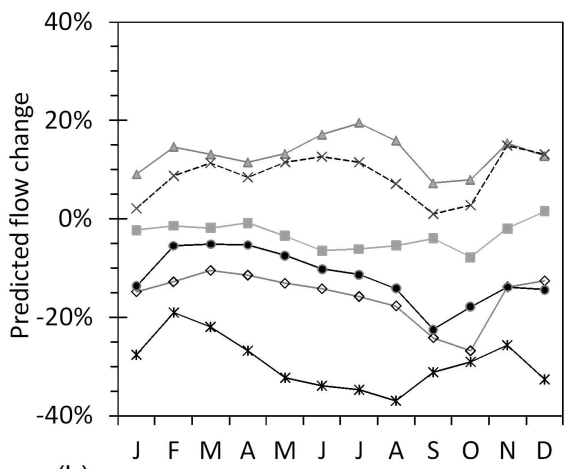

(b)

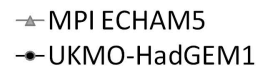

$\rightarrow-$ HadCM3 $\quad$ *IPSL CM4 - -UKMO-HadGEM1

Fig. 7. Projected changes in mean monthly river flow under the A1b SRES emissions scenario from six priority GCMs in the Rio Grande basin (a) and relative to 584 the detrended 1961-1990 baseline or control run (b).

for all durations. For the extreme scenario of $+6^{\circ} \mathrm{C}$, the increase would be from $5579 \mathrm{~m}^{3} \mathrm{~s}^{-1}$ in baseline to $8564 \mathrm{~m}^{3} \mathrm{~s}^{-1}$ for $5 \%$ duration and from $713 \mathrm{~m}^{3} \mathrm{~s}^{-1}$ to $897 \mathrm{~m}^{3} \mathrm{~s}^{-1}$ for $95 \%$ duration.

\subsection{Uncertainty in GCM structure}

Model results when meteorological inputs from different GCMs (CCCMA, CSIRO, ECHAM, IPSL, HadCM3, HadGEM1) for the A1b emission scenario are compared with those results obtained by running the hydrological model with the detrended baseline (Table 5). As above, the HadCM3 GCM projects a $+9 \%$ increase in mean river discharge whereas the new generation HadGEM1 model projects a $+10 \%$ decrease. Two other GCMs (CCCMA and IPSL), suggest that river flow will decrease by larger amounts whilst the CSIRO GCM shows a negligible reduction of river flow. In addition to HadCM3, the ECHAM5 GCM produces an increase in mean river discharge. Figure 7 shows that the predictions of increase or decrease are more or less evenly distributed over the year, although some of the models (IPSL, CCCMA, HadGEM1) show the most intense reductions during the late dry season or early wet season (August to October). Figure 8 reveals that increasing or decreasing results are evenly distributed over the whole range of streamflow values, from low flows to high flows.

Results from the six priority GCMs for a prescribed increase in global mean air temperature of $2{ }^{\circ} \mathrm{C}$ are summarised in Table 6. Projected changes in mean river discharge for the same rise $\left(2{ }^{\circ} \mathrm{C}\right)$ in global mean air temperature range considerably over the six applied GCMs from $-20 \%$ (IPSL) to $+18 \%$ (ECHAM5); two GCMs (HadGEM, NCAR) project negligible $(<2 \%)$ changes in mean annual river discharge. Three GCMs (HadCM3, ECHAM5, CSIRO) project substantial increases ( $+8 \%$ to $18 \%)$ in the mean discharge of Rio Grande. Two GCMs (IPSL, CCCMA) project decreases $(-4 \%$ to $-20 \%)$ in mean river flow (Fig. 9).

As reported above, the common focus in climate change studies on projected changes in mean river flow can mask important intra-annual (seasonal) changes in river flow. For 
Table 5. Hydrological modelling results using the same greenhouse emission scenario (A1B) and projections from different global circulation models. Control run was calculated using 95 years, from 2006 to 2100.

\begin{tabular}{|c|c|c|c|c|c|c|c|}
\hline & СССМА & CSIRO & ECHAM5 & HadCM3 & IPSL & HadGEM1 & $\begin{array}{l}\text { Control } \\
\text { run }\end{array}$ \\
\hline $\begin{array}{l}\text { Average river flow } \\
\left(\mathrm{m}^{3} \mathrm{~s}^{-1}, \% \text { change }\right)\end{array}$ & $2152,-14 \%$ & $2446,-2 \%$ & $2831,+13 \%$ & $2731,+9 \%$ & $1816,-28 \%$ & $2247,-10 \%$ & 2508 \\
\hline $\begin{array}{l}95 \% \text { duration flow } \\
\left(\mathrm{m}^{3} \mathrm{~s}^{-1}, \% \text { change }\right)\end{array}$ & $507,-30 \%$ & $681,-6 \%$ & $787,+8 \%$ & $710,-2 \%$ & $362,-50 \%$ & $565,-22 \%$ & 726 \\
\hline $\begin{array}{l}5 \% \text { duration flow } \\
\left(\mathrm{m}^{3} \mathrm{~s}^{-1}, \% \text { change }\right)\end{array}$ & $5123,-10 \%$ & $5636,-1 \%$ & $6357,+12 \%$ & $6335,+12 \%$ & $4520,-20 \%$ & $5353,-6 \%$ & 5667 \\
\hline
\end{tabular}

Table 6. Hydrological modelling results using the same mean global temperature rise scenario $\left(+2{ }^{\circ} \mathrm{C}\right)$ and projections from different global circulation models. Control run was calculated using 30 years, from 2040 to 2069.

\begin{tabular}{|c|c|c|c|c|c|c|c|}
\hline & СССМА & CSIRO & ECHAM5 & HadGEM1 & NCAR & IPSL & $\begin{array}{l}\text { Control } \\
\text { run }\end{array}$ \\
\hline $\begin{array}{l}\text { Average river flow } \\
\left(\mathrm{m}^{3} \mathrm{~s}^{-1}, \% \text { change }\right)\end{array}$ & $2382,-4 \%$ & $2677,+8 \%$ & $2924,+18 \%$ & $2445,-1 \%$ & $2534,+2 \%$ & $1989,-20 \%$ & 2475 \\
\hline $\begin{array}{l}95 \% \text { duration flow } \\
\left(\mathrm{m}^{3} \mathrm{~s}^{-1}, \% \text { change }\right)\end{array}$ & $596,-16 \%$ & $758,+6 \%$ & $835,+17 \%$ & $600,-16 \%$ & $673,-6 \%$ & $468,-34 \%$ & 713 \\
\hline $\begin{array}{l}5 \% \text { duration flow } \\
\left(\mathrm{m}^{3} \mathrm{~s}^{-1}, \% \text { change }\right)\end{array}$ & $5575,0 \%$ & $6045,+8 \%$ & $6569,+18 \%$ & $5756,+3 \%$ & $6045,+8 \%$ & $4892,-12 \%$ & 5579 \\
\hline
\end{tabular}

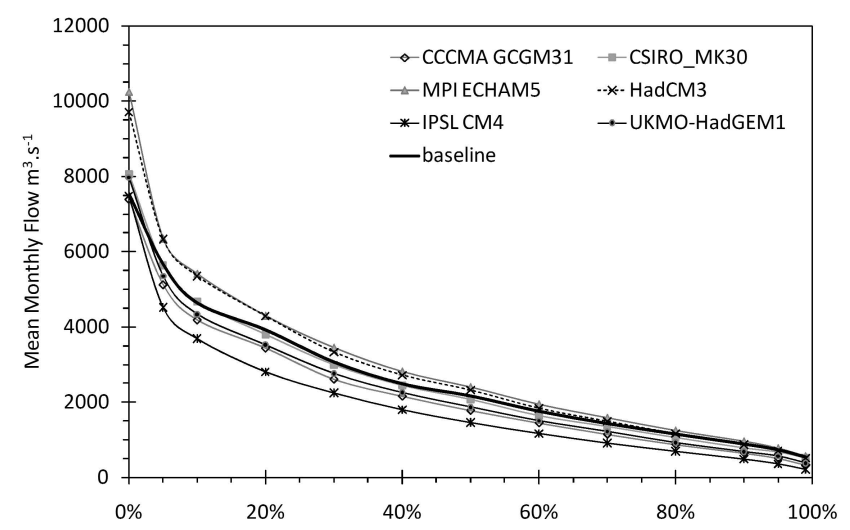

Fig. 8. Projected mean monthly flow duration curves under the A1b SRES emissions scenario from six priority GCMs in the Rio Grande basin along with the detrended 1961-1990 baseline or control run.

instance, projected declines in low flows under the A1b emissions scenario (Table 5) for CCCMA $(-30 \%)$ and HadGEM $(-50 \%)$ are considerably greater than those projected in mean river flow ( $-14 \%$ CCCMA, $-10 \%$ HadGEM). A similar result is observed for a projected $2{ }^{\circ} \mathrm{C}$ rise in global mean temperature (Table 6). Projected declines in the low flows are much greater than those projected for mean flows using IPSL $\left(\Delta Q_{95}=-34 \%, \Delta Q_{\text {mean }}=-20 \%\right)$ and CCCMA $\left(\Delta Q_{95}=-16 \%, \Delta Q_{\text {mean }}=-4 \%\right)$. In contrast, a projected increase in the low flow ( $+5 \%)$ under the A1b emissions scenario using IPSL is at odds with a large $(-28 \%)$ projected decline in mean river flow. The duration flow curve for such GCMs, Fig. 10, reveals that the behaviour of changes is the same no matter considered the high flows or the low flows, actually preserving the sign of changes.

\section{Conclusions}

Uncertainty in the impact of climate change on the discharge of Rio Grande, one of the most important rivers in Brazil for hydro-electric power generation, was assessed in terms of (1) GCM structure using a priority subset of six CMIP3/IPCC-AR4 GCMs, (2) emission scenarios, which are commonly adopted according to the IPCC Special Report on Emission Scenarios, and are called A1B, A2, B1 and $\mathrm{B} 2$, and prescribed increases in global mean air temperature of $1^{\circ} \mathrm{C}$ to $6^{\circ} \mathrm{C}$. A very consistent trend of increasing discharge is projected to occur if climate projections from a single GCM, HadCM3, are used as input to the hydrological model. Mean river discharge increases under SRES 


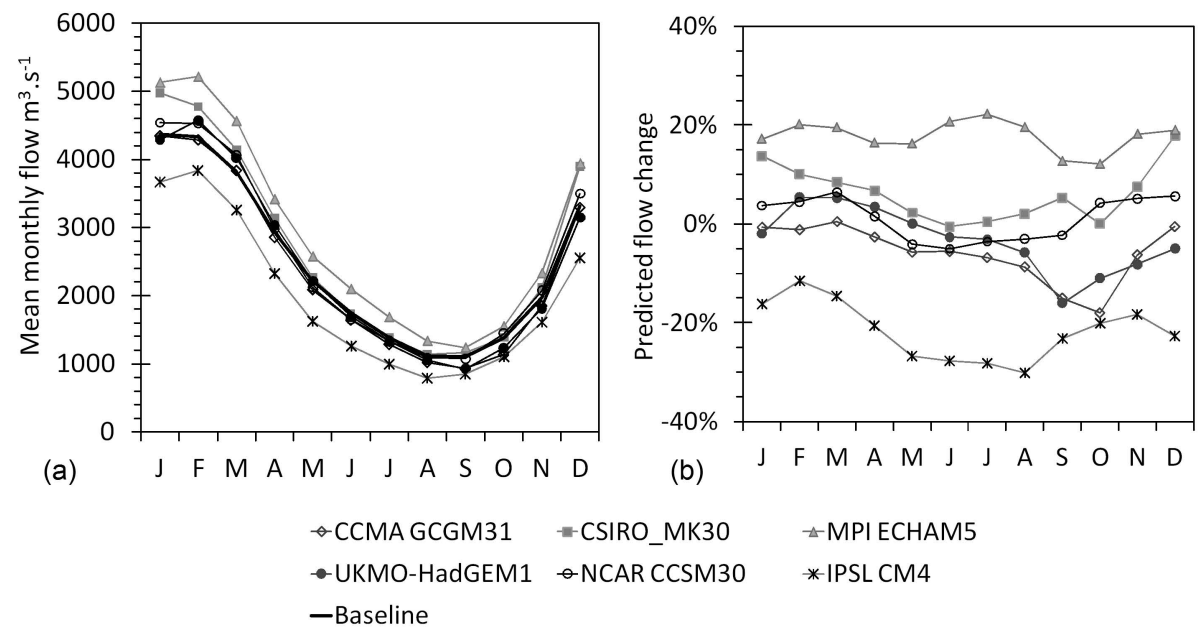

Fig. 9. Projected changes in mean monthly river flow under a mean global temperature rise of $+2{ }^{\circ} \mathrm{C}$ from six priority GCMs in the Rio Grande basin (a) and relative to the detrended 1961-1990 baseline or control run (b).

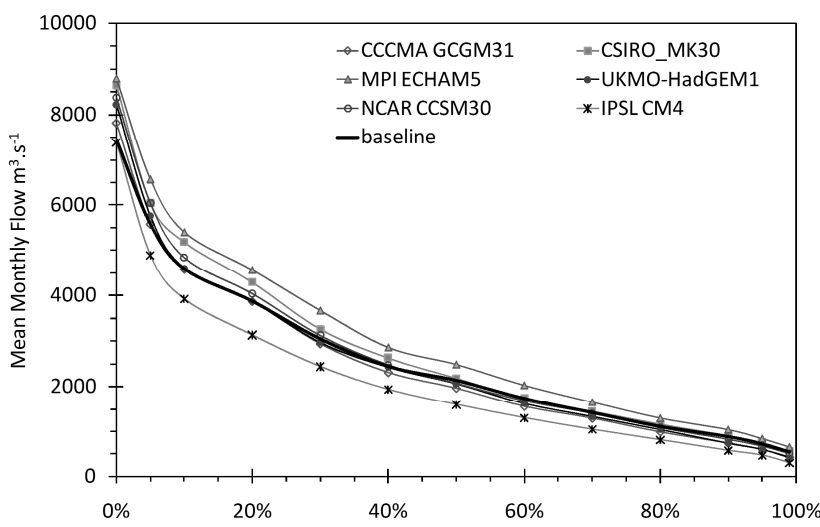

Fig. 10. Projected changes in mean monthly flow duration curves under a mean global temperature rise of $+2{ }^{\circ} \mathrm{C}$ from six priority GCMs in the Rio Grande basin along with the detrended 1961-1990 baseline or control run.

emissions scenarios $(+5 \%$ to $+10 \%)$ and prescribed increases in global mean air temperature $(+8 \%$ to $+50 \%)$. For the latter, a very clear trend is evident of increasing river flow with increasing mean global air temperature. For every $1^{\circ} \mathrm{C}$ increase in temperature the annual flow of Rio Grande increases by 8 to $9 \%$, in relation to the $1961-1990$ baseline. Low $\left(Q_{95}\right)$ and high $\left(Q_{05}\right)$ flows are also projected to increase except for the SRES emission scenarios where slight decreases in low flows are projected.

Quantified uncertainty in hydrological projections increases substantially when GCM structure is considered. Projected changes in mean river discharge relative to the 1961-1990 baseline for the same greenhouse gas emission scenario (A1b) using the six priority GCMs vary from $-28 \%$ to $+13 \%$. Under a rise in global mean air temperature of $+2{ }^{\circ} \mathrm{C}$, projected changes in mean river flow range from
$-20 \%$ to $+18 \%$, with at least two GCM showing no important changes in average flows at all.

These results are in accordance with findings of other authors who suggest that the choice of the GCM is the largest quantified source of uncertainty in projected impacts of climate change on river flow (Bates et al., 2008; Kay et al., 2009; Blöschl and Montanari, 2010; Paiva and Collischonn, 2010).

The range of output streamflow values could increase further if the analysis made here could be extended including additional sources of uncertainty, as initial conditions of the GCM runs, downscaling methods, and hydrological model structure and parameters (Krahe et al., 2009).

An ensemble mean of the different outputs may be considered as a form to summarize the projections (Nohara et al., 2006; Christensen and Lettenmaier, 2007), however in our case it would probably mask the results since nearly half of the GCMs suggest an increase while the other half suggest a decrease in streamflow.

Our results indicate that extreme caution should be exercised in results based on projections from a single GCM. Mistaken management decisions may follow. A $10 \%$ increase/decrease in discharge of the Grande River and the Parana, for example, would possibly affect power generation capacity, impacting planning decisions on the necessity and timing of the construction of new power plants. In the Brazilian case, for instance, an erroneous prediction of reduction in river flow, for example, could lead to acceleration in the pace of construction of new hydropower plants in the Amazon Basin or the increase in fossil fuel thermoelectric generation, which would not be justified.

Finally, the analysis made here for the Rio Grande should be replicated at the national scale, in order to assess if other river basins show the same level of uncertainty related to GCMs. 
Acknowledgements. Financial assistance for the first activities of this research was provided by FINEP/CT-Hidro Financiadora de Estudos e Projetos) from the Brazilian Ministry of Science and Technology (MCT). The first author acknowledges the support of Brazilian National Water Agency (ANA). The fourth author was supported by Conselho Nacional de desenvolvimento Científico e Tecnológico (CNPq). This work was supported, in part, by a grant from the UK Natural and Environmental Research Council (NERC), under the Quantifying and Understanding the Earth System (QUEST) programme (Ref. NE/E001890/1). The authors are very grateful to early reviews of the manuscript by Richard Taylor and Julian Thompson that improved its clarity.

Edited by: R. Taylor

\section{References}

Allasia, D., Collischonn, W., Silva, B. C., and Tucci, C. E. M.: Large basin simulation experience in South America, in: Predictions in Ungauged Basins: Promises and Progress, edited by: Sivapalan, M., Wagener, T., Uhlenbrook, S., Zehe, E., Lashmi, V., Liang, X., Tachikawa, Y., and Kumar, P., IAHS Publ., IAHS Press, Wallingford, UK, 303, 360-370, 2006.

Ambrizzi, T., Rocha, R., Marengo, J. A., Pisnitchenko, I., and Alves, L.: Cenários regionalizados de clima no Brasil para o Século XXI: Projeções de clima usando três modelos regionais, Relatório 3, Ministério do Meio Ambiente - MMA, Secretaria de Biodiversidade e Florestas - SBF, Diretoria de Conservação da Biodiversidade - DCBio Mudanças Climáticas Globais e Efeitos sobre a Biodiversidade - Sub projeto: Caracterização do clima atual e definição das alterações climáticas para o território brasileiro ao longo do Século XXI, Brasília, 2007.

ANA, Agência Nacional de Águas: HidroWeb - Sistema de Informações Hidrológicas, http://hidroweb.ana.gov.br, last access: 1 August, 2005.

ANEEL, Agência Nacional de Energia Elétrica: Brazilian Electric Energy Atlas, edn 2, Brasília, 2005.

Barros, V., Clarke, R. T., and Silva Dias, P. L.: El cambio climático en la cuenca del Plata, CIMA/CONICET, Buenos Aires, Argentina, 2006.

Bastidas, L. A., Gupta, H. V., and Sorooshian, S.: Emerging paradigms in the calibration of hydrologic models, in: Mathematical Models of Large Watershed Hydrology, edited by: Singh, S. and Frevert, D. K., Water Resources Publications, Littleton, Colorado, USA, 25-66, 2002.

Bates, B. C., Kundzewicz, Z. W., Wu, S., and Palutikof, J. P.: Climate Change and Water, Technical Paper of the Intergovernmental Panel on Climate Change, IPCC Secretariat, Geneva, 210 pp., 2008.

Beven, K.: Rainfall-Runoff Modelling: The Primer, Wiley, Chichester, UK, 2001.

Blöschl, G. and Montanari, A.: Climate change impacts - throwing the dice?, Hydrol. Process., 24, 374-381, doi:10.1002/hyp.7574, 2010.

Bravo, J. M., Paz, A. R., Collischonn, W., Uvo, C. B., Pedrollo, O. C., and Chou, S. C.: Incorporating forecasts of rainfall in two hydrologic models used for medium-range streamflow forecasting, J. Hydrol. Eng., 14(5), 435-445, doi:10.1061/(ASCE)HE.19435584.0000014, 2009.
Chou, S., Nunes, A., and Cavalcanti, I.: Extended range forecasts over South America using the regional ETA model, J. Geophys. Res., 105(D8), 10147-10160, doi:10.1029/1999JD901137, 2000.

Christensen, N. S. and Lettenmaier, D. P.: A multimodel ensemble approach to assessment of climate change impacts on the hydrology and water resources of the Colorado River Basin, Hydrol. Earth Syst. Sci., 11, 1417-1434, doi:10.5194/hess-11-14172007, 2007.

Collischonn, B., Collischonn, W., and Tucci, C. E. M.: Daily hydrological modeling in the Amazon basin using TRMM rainfall estimates, J. Hydrol., 360(1-4), 207-216, doi:10.1016/j.jhydrol.2008.07.032, 2008.

Collischonn, W., Clarke, R. T., and Tucci, C. E. M.: Fluctuations in hydrological regime of the River Paraguai: part of a wider phenomenon of climate change?, J. Hydrol., 245(1-4), 218-238, doi:10.1016/S0022-1694(01)00348-1, 2001.

Collischonn, W., Haas, R., Andreolli, I., and Tucci, C. E. M.: Forecasting River Uruguay flow using rainfall forecasts from a regional weather prediction model, J. Hydrol., 305(1-4), 87-98, doi:10.1016/j.jhydrol.2004.08.028, 2005.

Collischonn, W., Allasia, D. G., Silva, B. C., and Tucci, C. E. M.: The MGB-IPH model for large-scale rainfall-runoff modeling, Hydrolog. Sci. J., 52(5), 878-895, doi:10.1623/hysj.52.5.878, 2007a.

Collischonn, W., Tucci, C. E. M., Clarke, R. T., Chou, S. C., Guilhon, L. G., Cataldi, M., and Allasia, D. G.: Medium-range reservoir inflow predictions based on quantitative precipitation forecasts, J. Hydrol., 344, 1-2, 112-122, doi:10.1016/j.jhydrol.2007.06.025, 2007b.

Dettinger, M. D. and Diaz, H. F.: Global characteristics of stream flow seasonality and variability, J. Hydrometeorol., 1(4), 289310, 2000.

Kay, A. L., Davies, H. N., Bell, V. A., and Jones, R. G.: Comparison of uncertainty sources for climate change impacts: flood frequency in England, Climatic Change, 92(1-2), 41-63, doi:10.1007/s10584-008-9471-4, 2009.

Kouwen, N., Soulis, E. D., Pitroniro, A., Donald, J., and Harrington, R. A.: Grouped response units for distributed hydrologic modeling, J. Water Res. Pl.-ASCE, 119(3), 289-305, 1993.

Krahe, P., Nilson, E., Carambia, M., Maurer, T., Tomassini, L., Büllow, K., Jacob, D., and Moser, H.: Wirkungsabschätzung von Unsicherheiten der Klimamodellierung in Abflussprojektionen Auswertung eines Multimodell-Ensembles im Rheingebiet, Estimating the consequences for projections of river discharges resulting from uncertainties in climate-change modelling - Analysis of an application of a multi-model ensemble in the catchment of the River Rhine, Hydrol. Wasserbewirts., 53(5), 316331, 2009.

Marengo, J. A.: Integrating across spatial and temporal scales in climate projections: Challenges for using RCM projections to develop plausible scenarios for future extreme events in South America for vulnerability and impact studies, IPCC TGICA Expert Meeting on Integrating Analysis of Regional Climate Change and Response Options, Meeting Report: Papers, Nadi, Fiji, 141-147, 2007.

Mitchell, T. D. and Jones, P. D.: An improved method of constructing a database of monthly climate observations and associated high-resolution grids, Int. J. Climatol., 25, 693-712, 2005. 
Motta, J. C. and Tucci, C. E. M.: Simulation of urbanization effect in flow, Hydrolog. Sci. J., 29(2), 131-147, doi:10.1080/02626668409490930, 1984.

Nohara, D., Kitoh, A., Hosaka, M., and Oki, T.: Impact of climate change on river discharge projected by multimodel ensemble, $\mathrm{J}$. Hydrometeorol., 7, 1076-1089, 2006.

ONS, National System Operator: Stream flow Series Update 1931-2006, Tech. Rep., 2007.

Osborn, T. J.: A user guide for ClimGen: a flexible tool for generating monthly climate data sets and scenarios, Climatic Research Unit, University of East Anglia, Norwich, 17 pp., 2009.

Paiva, R. C. D. and Collischonn, W.: Climate change impacts on river Quarai flow, in: Climate and Water Resources Modelling, edited by: Fung, C. F., Lopez, A., and New, M., John Willey \& Sons, 200 pp., 2010.

Paz, A. R. and Collischonn, W.: River reach length and slope estimates for large-scale hydrological models based on a relatively high-resolution digital elevation model, J. Hydrol., 343, 127139, doi:10.1016/j.jhydrol.2007.06.006, 2007.

Peel, M. C., McMahon, T. A., Finlayson, B. L., and Watson, F. G. R.: Identification and explanation of continental differences in the variability of annual runoff, J. Hydrol., 250(1-4), 224-240, doi:10.1016/S0022-1694(01)00438-3, 2001.

Robertson, A. W. and, Mechoso, C. R.: Interannual and decadal cycles in river flows of southeastern South America, J. Climate, 11, 2570-2581, 1998.

Schaeffer, R., Szklo, A. S., Lucena, A. F. P., Souza, R. P., Borba, B. S. M. C., Costa, I. V. L., Pereira, A., and Cunha, S. H. F.: Climate change: energy security, Final Report, PPE/COPPE/UFRJ, Rio de Janeiro, 2008.
Timilsena, J., Piechota, T., Tootle, G., and Singh, A:. Associations of interdecadal/interannual climate variability and longterm Colorado river basin streamflow, J. Hydrol., 365, 289-301, doi:10.1016/j.jhydrol.2008.11.035, 2009.

Todd, M. C., Taylor, R. G., Osborne, T., Kingston, D., Arnell, N. W., and Gosling, S. N.: Quantifying the impact of climate change on water resources at the basin scale on five continents - a unified approach, Hydrol. Earth Syst. Sci. Discuss., 7, 7485-7519, doi:10.5194/hessd-7-7485-2010, 2010.

Tomasella, J., Rodriguez, D. A., Cuartas, L. A., Ferreira, M., Ferreira, J. C., and Marengo, J.: Study of the climate change impacts on surface water resources and groundwater levels in the Tocantins river basin, 2008.

Tucci, C. E. M. and Clarke, R. T.: Adaptive forecasting with a conceptual rainfall-runoff model, in: Hydrological forecasting, Proceedings of the Oxford symposium IAHS, 129, 425-454, 1980.

Tucci, C. E. M. and Damiani, A.: Potential impacts of climate change on the Uruguay river, Revista Brasileira de Engenharia - Caderno de Recursos Hídricos, ABRH, 12, 2, 1994.

Tucci, C. E. M., Clarke, R. T., Collischonn, W., Dias, P. L. S., and Sampaio, G.: Long term flow forecast based on climate and hydrological modeling: Uruguay River basin, Water Resour. Res., 39(7), 1181, doi:10.1029/2003WR002074, 2003.

Tucci, C. E. M., Collischonn, W., Clarke, R. T., Paz, A. R., and Allasia, D.: Short- and long-term flow forecasting in the Rio Grande watershed (Brazil), Atmos. Sci. Lett., 9(2), 53-56, doi:10.1002/asl.165, 2008.

Yapo, P. O., Gupta, H. V., and Sorooshian, S.: Multi-objective global optimization for hydrologic models, J. Hydrol., 204, 83 97, 1998. 